\title{
Causes of Construction Projects Cost Overrun in Brazil
}

\author{
Alda França ${ }^{1}$, Assed Haddad ${ }^{1}$ \\ ${ }^{1}$ Construction Engineering Department, Universidade Federal do Rio de Janeiro, Rio de Janeiro, Brazil \\ *Corresponding E-mail: assed@ poli.ufrj.br
}

Received 12 October 2017; Revised 30 May 2018; Accepted 19 June 2018

DOI: https://10.30880/ijscet.2018.09.01.006

\begin{abstract}
This paper presents a survey on construction projects cost performance in Brazil with an analysis of cost overrun causes of the works based on the contractors' point of view. After a literature review and field research, several causes were identified and evaluated by frequency, severity, and importance through a questionnaire. The field survey conducted included 11 directors, 17 project managers and 19 area managers of different construction companies. Eighty-five causes of cost overrun were identified and classified in 11 departments with internal and external influences. The research shows that $71 \%$ of the 238 contracts of the study have their costs exceeded, being $82 \%$ in amounts up to $25 \%$ of the initial agreement and $18 \%$ above $25 \%$. The most striking causes identified by the three parties were the change of scope, lack of design detail during budgeting, and high indirect cost in a period of low productivity.
\end{abstract}

Keywords: Construction projects, Cost overrun causes, Brazilian construction

\subsection{Introduction}

The main objective of contractors is to complete their projects within appropriate planned cost and time, but mainly profitability. However, it is not what reflects most of the works contracts in Brazil. Through the presentation and analysis of a series of cases, studies show that construction projects have a common characteristic of non-compliance with the initial agreed costs, affecting the financial and economic performance of the works. It is important to explain that when analyzing through the contractor's view if the cost increase is linked to the additive scope combined with increased revenue while maintaining final profitability, this is no longer the subject of discussion in this study.

However, the construction projects are subject to several external and internal factors that directly affect the cost of a work. Those factors are environmental factors; political factors; market factors; customer behavior; factors related to the performance and directives of the management and contract management; factors related to the performance of the work departments such as commercial and contractual administration, engineering and consulting, budgeting, planning and cost control, production, quality, environment and health. The relation of causes to each of these factors is of extreme importance to identify which department most influence cost increase of a work.

\subsection{Objectives of the Study}

The study aims to identify the main causes of cost overrun, the loss of profitability of a construction project, in works of the public, private and mixed contracts types in Brazil, as well as the main factors related to them. The focus of this case study is the budget analysis in the view of the contractor rather than client. For that, we interviewed professionals from the area of 27 different 
companies, who underwent works in 16 states of the country and who have great experience in the construction projects.

The paper covers three important hierarchical levels point of view within construction companies. First, directors, which have a strategic view of all projects and responds directly to shareholders regarding the profitability of the contracts. Then, project managers who are the highest level within a work, responsible for managing and ensuring the interaction between the departments and the profitability of the contract through the effective performance of management in all areas. Finally, the area managers who are the ones who create the budgets, execute the works, carry out the acquisitions, control and monitor cost and planning.

With the analysis through these three hierarchical levels, one can obtain an internal view of the company in the identification and analysis of the main causes of the increase of cost through 3 different points of view, but of great relevance in the five phases of the life cycle of a project.

\subsection{Literature Review}

Studies presented in various articles indicate that the problem of cost increase is common to several countries and that the causes are recurrent. The poor performance of public works in relation to cost increases and delivery times, compared to expected values, has been recurrent in Brazil and other emerging countries (Santos et al., 2015).

Santos et al. (2015) [1] in a study on the causes of cost increases and deadlines in municipal public building works in Belo Horizonte concluded that $72 \%$ of the 145 works evaluated presented a cost increase, very similar with this present study in which $71 \%$ of 238 contracts under study showed a cost increase. Santos et al. still present in their study that the two most important causes regarding the delay of the works are related to the lack of compatibility of the projects and error in the quantitative survey. In this present study, these causes were also pointed out as of great importance in the view of area managers.

Senouci et al. (2016) [8] in his study on the increase of term and cost in 122 construction contracts in Qatari shows that 54\% had their costs increased and 72\% their deadlines increased.

Niazi and Painting (2016) [2] present corruption, late payment by the client and financial difficulties on the part of the construction companies as the three main causes of the increase in construction costs in Afghanistan. But, among the ten most important causes present the delay in the approval of the projects, which in this present study is among the most important causes in common agreement of all the interviewees.

Azhar et al. (2008) [3] in a study on causes of cost increase in works in Pakistan show that the main causes are related to variation in materials prices, high equipment costs. However, the top 10 are also related to the lack of cost control, which in this present study is evaluated as one of the causes of greater impact in the project managers' view.

Similar to the studies cited above, Aziz et al. (2013) [4] in their study in works in Malaysia, have as main causes the variation of materials prices, cash flow and financial difficulties on the part of the constructors. Although in the present study these causes are pointed out, they are not among the ten most relevant. Enshassi et al. (2009) [5] also presents as the main cause of the cost increase the variation of the price of the materials.

Sawalhi (2015) [6] conducts an evaluation of indirect costs in construction projects in the Gaza Strip and presents the impact and importance of these costs on a construction site. The high indirect cost in periods of low productivity is the third most important cause among the 85 presented in the present study.

Assaf and Al-Hejji (2006) [7] in research on causes of the increase of the term in construction projects in Saudi Arabia interview 23 contractors whose results of the most relevant causes in their visions are delay in payment by the client, delay in review and approval of the projects and 
modification of the execution sequence of the work. These causes directly impact the cost of the works as can be observed in the present study.

Kaming et al. (1997) [9] in a study of construction projects in two cities in Indonesia show that the increase in the price of materials due to inflation, the error in the estimation of materials and the complexity of the projects are the main causes of the cost increase. Arditi et al. (1985) [10] presents a similar result in his study in Turkey.

Cheng (2014) [11] presents a research result in which change in scope and cost control are the most relevant causes. Already Polat et al. (2014) [12] identified project changes and delays in project approval as more critical factors. These two studies present very similar results with the present study.

Based on this literature review, the causes of cost overrun in construction projects in Brazil were analyzed and listed based on the evaluation of several professionals in the industry. Their experiences contributed to other causes until reaching the 85 introduced in the present study.

\subsection{Research Methodology}

The research methodology consisted in the identification of 85 causes of cost increase through the literature review and field research with professionals in the area. Subsequently, these causes were distributed in 11 departments. Following a questionnaire was elaborated being divided into two stages: the first one with the objective to qualify the interviewed ones by obtaining information on the career and data of the works lived by them. The second, focused on the evaluation of the frequency and severity of the causes listed. Subsequently, an analysis of the data collected in the second stage was carried out through frequency, severity and importance indexes.

The interview includes 47 professionals, such as 11 directors, 17 project managers and 19 area managers with experience in 27 different construction companies. The answers were based on the experience of 238 small, medium and large works.

\subsection{Questionnaire Design}

In order to prepare a questionnaire, it was necessary, in the first stage, to obtain the data related to the interviewees' profile, such as the position held, the number of years of experience, the number of works done, the types of work, the types of contract and the percentage of cost increase on those projects.

The second part of the questionnaire is related to the evaluation of the causes of cost overruns. The Liker scale was evaluated from 1 to 5 for frequency and severity. The frequency of the cause event was characterized as: does not occur, low frequency, medium frequency, high frequency and extreme frequency. The severity follows a similar category being: no severity, low severity, medium severity, high severity and extreme severity. The collected data were then compiled according to the approach described below.

\subsection{Data Analysis Approach}

For the analysis of the data, the following statistical formulas were applied:

(FI) Frequency Index: This formula is used to list the causes identified according to their frequency from the evaluation of each interviewee.

$$
F I(\%)=\sum \frac{A f}{A \times N}
$$

Where: 
$\sum A f=$ sum of the weight of the frequency reported by each interviewee from 1 to 5 for the presented cause;

$\mathrm{A}=$ highest weight, which in this case is equal to 5, highest category of the Likert scale adopted in this study; and

$\mathrm{N}=$ total number of responses to that cause;

This formula must be applied for each cause.

(RII) Index of Relative Importance or (SI) Severity Index: This formula is used to list the causes identified according to their severity or impact based on the evaluation of each interviewee.

$R I I=S I=\sum \frac{W}{A \times N}$

Where:

$\sum W=$ sum of the impact weight reported by each interviewee from 1 to 5 for the cause presented; $\mathrm{A}=$ highest weight, which in this case is equal to 5, highest category of the Likert scale adopted in this study; and

$\mathrm{N}=$ total number of responses to that cause;

This formula must be applied for each cause.

(IMPI) Importance Index: This formula is used to list the identified causes according to their importance from the evaluation of each interviewee and is obtained by multiplying the IF index by the SI.

$\operatorname{IMPI}(\%)=F I \times S I(3)$

Finally, was calculated the Spearman correlation coefficient $\left(r_{s}\right)$ which is a non-parametric test whose result varies from -1 to +1 , with +1 signifying a total agreement between the candidate groups and -1 total disagreement [7]. Closer to 1 the result means a good correlation of the analyzed groups. This coefficient was applied to the results of the 3 possible combinations: Directors with Project managers; Directors with Area Managers and Area Managers with Project managers, using the following formula:

$r_{s}=1-\frac{6 \quad d}{n\left(n^{2}-1\right)}(4)_{\sum 2}$

Where:

$\mathrm{d}=$ difference between the classifications of the 2 groups analyzed; and $\mathrm{n}$

$=$ number of analyzed data.

The results obtained with the application of these statistical formulas will be presented in several tables that will be exposed in the following item.

\subsection{Results and Discussions}

Data were collected based on 238 contracts distributed in 16 states of the country as shown in Figure 1. 


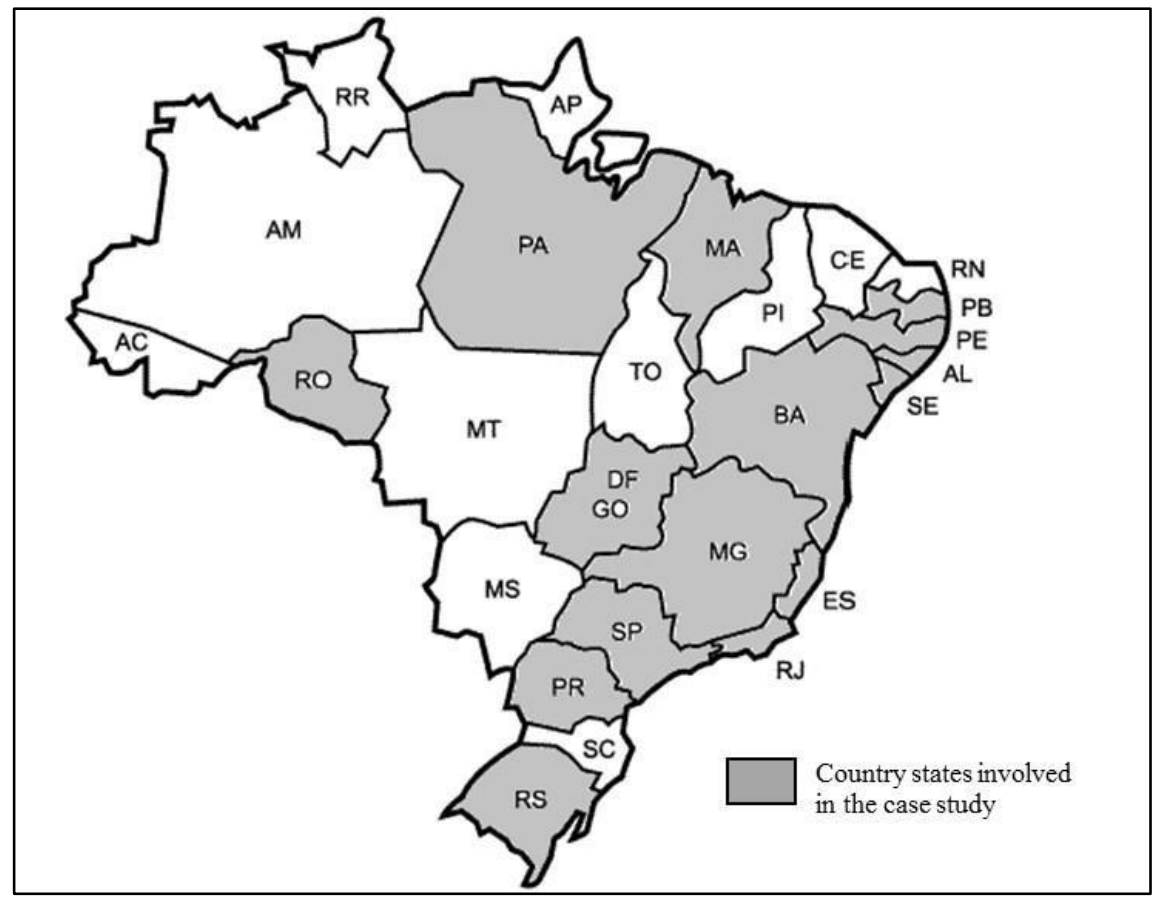

Figure 1: Country states involved in the case study. Source: (Author, 2017)

In the first stage of the questionnaire, data were collected regarding the characteristics of the respondents and their different experiences, as can be observed in Table 1 and Figure 2.

Table 1: Characteristics of respondents

\begin{tabular}{|c|c|c|c|}
\hline Parameters & Quantity & Percentage (\%) & Cumulative (\%) \\
\hline \multicolumn{4}{|l|}{ Respondent's Position } \\
\hline Director & 11 & $23 \%$ & $23 \%$ \\
\hline Project manager & 17 & $36 \%$ & $60 \%$ \\
\hline Area Managers & 19 & $40 \%$ & $100 \%$ \\
\hline \multicolumn{4}{|l|}{ Experience (years) } \\
\hline Director & 28 & $38 \%$ & $38 \%$ \\
\hline Project manager & 17 & $35 \%$ & $74 \%$ \\
\hline Area Managers & 11 & $26 \%$ & $100 \%$ \\
\hline \multicolumn{4}{|l|}{ Types of Projects } \\
\hline Buildings & 71 & $30 \%$ & $30 \%$ \\
\hline Infrastructure & 125 & $53 \%$ & $82 \%$ \\
\hline Industrial Projects & 38 & $16 \%$ & $98 \%$ \\
\hline Offshore and onshore oil platform & 4 & $2 \%$ & $100 \%$ \\
\hline \multicolumn{4}{|l|}{ Contract Types } \\
\hline Public & 120 & $50 \%$ & $50 \%$ \\
\hline Private & 105 & $44 \%$ & $95 \%$ \\
\hline Public Private & 13 & $5 \%$ & $100 \%$ \\
\hline \multicolumn{4}{|l|}{ Size of Projects } \\
\hline 0 - 35 Million (USD) & 109 & $46 \%$ & $46 \%$ \\
\hline 35 - 100 Million (USD) & 61 & $26 \%$ & $71 \%$ \\
\hline 100 - 350 Million (USD) & 47 & $20 \%$ & $91 \%$ \\
\hline
\end{tabular}




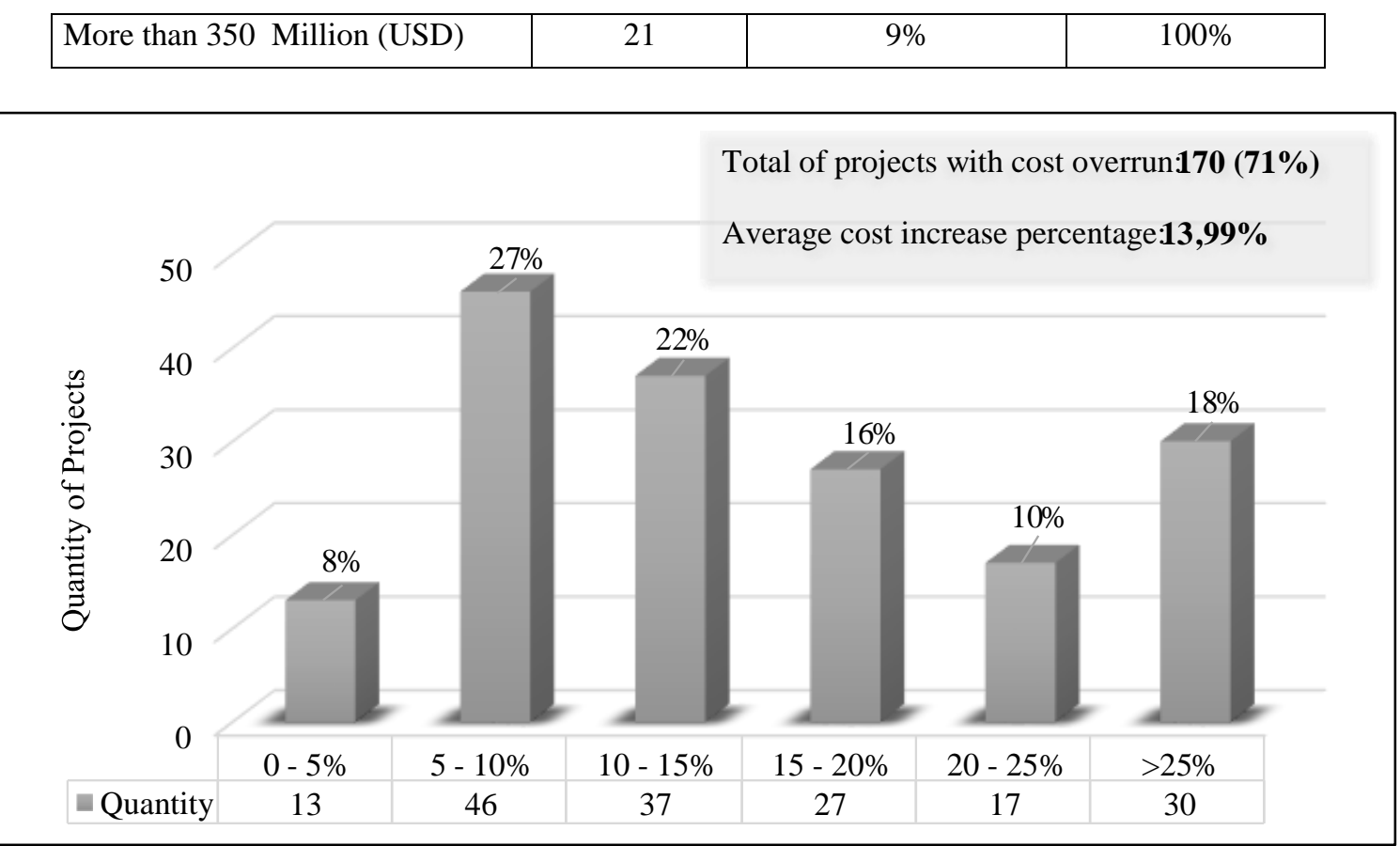

Figure 2: Percentage of Cost Overrun in Projects. Source: (Author, 2017)

Subsequently, the second stage of the questionnaire consisted in the evaluation of the 85 causes of cost increase classified by each department, identified in Table 2.

Table 2: List of causes of cost overrun categorized into eleven departments

\begin{tabular}{|c|l|l|}
\hline No & \multicolumn{1}{|c|}{ Cost overrun Causes } & \multicolumn{1}{|c|}{ Departments } \\
\hline 1 & Changes / additives in scope & Client \\
\hline 2 & Undefined scope & Client \\
\hline 3 & Political pressures to meet deadlines & Client \\
\hline 4 & Frequent change orders during construction by client & Client \\
\hline 5 & Delay in progress payments by client & Client \\
\hline 6 & Delayed delivery of the site by the client & Client \\
\hline 7 & Unrealistic contractual deadlines & Client \\
\hline 8 & Customer contractual suspension & Client \\
\hline 9 & Delay in decision making by the client & Client \\
\hline 10 & Restrictions such as expropriations and interference & Client \\
\hline 11 & Lack / inefficiency of contract administration & $\begin{array}{l}\text { Commercial / Contractual } \\
\text { Administration }\end{array}$ \\
\hline 12 & Lack of qualification of subcontractors & $\begin{array}{l}\text { Commercial / Contractual } \\
\text { Administration }\end{array}$ \\
\hline 13 & Constant changes of subcontractors & $\begin{array}{l}\text { Commercial / Contractual } \\
\text { Administration }\end{array}$ \\
\hline 14 & Lack of knowledge of subcontractors & $\begin{array}{l}\text { Commercial / Contractual } \\
\text { Administration }\end{array}$ \\
\hline 15 & $\begin{array}{l}\text { Contracts poorly negotiated with subcontractors (measurement } \\
\text { criteria, unit cost, payment term, etc.) }\end{array}$ & $\begin{array}{l}\text { Commercial / Contractual } \\
\text { Administration }\end{array}$ \\
\hline 16 & Constant equipment failure & $\begin{array}{l}\text { Commercial / Contractual } \\
\text { Administration }\end{array}$ \\
\hline
\end{tabular}


$17 \quad$ Purchase of low quality materials

Commercial / Contractual

Administration

\begin{tabular}{|c|c|c|}
\hline No & Cost overrun Causes & Departments \\
\hline 18 & Delay in delivery of materials & $\begin{array}{l}\text { Commercial / Contractual } \\
\text { Administration }\end{array}$ \\
\hline 19 & $\begin{array}{l}\text { Financial difficulty on the part of the company causing delay in the } \\
\text { payment of the resources mobilized }\end{array}$ & Directorship \\
\hline 20 & Lack of interaction between directors and project managers & Directorship \\
\hline 21 & Lack of experience of the company in the construction type & Directorship \\
\hline 22 & Excessive internal procedures & Directorship \\
\hline 23 & Lack of internal procedures & Directorship \\
\hline 24 & Increase in Central Administration Fee & Directorship \\
\hline 25 & Unrealistic initial budget assumptions & Directorship \\
\hline 26 & Late in reviewing design documents & Engineering / Consulting \\
\hline 27 & Complexity of project design & Engineering / Consulting \\
\hline 28 & $\begin{array}{l}\text { Lack of communication and integration between } \\
\text { consultants/engineering sector with other parties }\end{array}$ & Engineering / Consulting \\
\hline 29 & Slow information delivery (Ex: Technical queries) & Engineering / Consulting \\
\hline 30 & Conflicts between consultants/engineering sector with other parties & Engineering / Consulting \\
\hline 31 & Project design incompatibility & Engineering / Consulting \\
\hline 32 & Mistakes in design documents & Engineering / Consulting \\
\hline 33 & Delay in the preparation of design projects & Engineering / Consulting \\
\hline 34 & Extreme weather factors (rains, winds, heat.) & Environmental Factors \\
\hline 35 & Natural disasters & Environmental Factors \\
\hline 36 & Archaeological interferences at the site & Environmental Factors \\
\hline 37 & Interference of fauna and flora & Environmental Factors \\
\hline 38 & Corruption & Political Factors \\
\hline 39 & Effects of social and cultural factors & Political Factors \\
\hline 40 & Problems with public services & Political Factors \\
\hline 41 & Excessive bureaucracy on the part of public entities & Political Factors \\
\hline 42 & Change of norms and laws & Political Factors \\
\hline 43 & Change of taxes & Political Factors \\
\hline 44 & Raise in the price of resources due to the increase in inflation & Political Factors \\
\hline 45 & Change of national currency & Political Factors \\
\hline 46 & Exchange variation & Political Factors \\
\hline 47 & $\begin{array}{l}\text { Variation in the price of commodities (Oil, ethanol, wheat, aluminum } \\
\text {,.) }\end{array}$ & Political Factors \\
\hline 48 & Permission for foreign jobs & Political Factors \\
\hline 49 & $\begin{array}{l}\text { Lack of security in the area of construction activities (robberies, } \\
\text { shootings, etc.) }\end{array}$ & Political Factors \\
\hline 50 & Lack of specialized labor & External \\
\hline 51 & High labor cost & External \\
\hline
\end{tabular}




\begin{tabular}{|c|c|c|}
\hline 52 & Lack of qualified labor & External \\
\hline 53 & Shortage of building materials and equipment on the market & External \\
\hline 54 & $\begin{array}{l}\text { High market demand by raising prices of resources (materials, } \\
\text { equipment, services, etc.) }\end{array}$ & External \\
\hline 55 & $\begin{array}{l}\text { Lack of interaction between production, engineering, planning, cost } \\
\text { and customer measurement sectors }\end{array}$ & Contract Management \\
\hline No & Cost overrun Causes & Departments \\
\hline 56 & Lack of team motivation due to non-active leadership & Contract Management \\
\hline 57 & Conflicts between area leaders & Contract Management \\
\hline 58 & Delays in the mobilization of construction sites and resources & Contract Management \\
\hline 59 & High indirect cost in periods of low productivity & Contract Management \\
\hline 60 & Lack of safety, environment and health management & Contract Management \\
\hline 61 & Inefficiency in identifying risks & Budget \\
\hline 62 & $\begin{array}{l}\text { Lack of knowledge of the real productivity in the elaboration of the } \\
\text { compositions }\end{array}$ & Budget \\
\hline 63 & Error in raising quantitative & Budget \\
\hline 64 & Lack of design detail during budgeting & Budget \\
\hline 65 & Lack of consideration of unproductiveness in the calculation of labor & Budget \\
\hline 66 & $\begin{array}{l}\text { Lack of consideration of social charges in the calculation of labor } \\
\text { cost }\end{array}$ & Budget \\
\hline 67 & $\begin{array}{l}\text { Lack of consideration of the aggregate cost in the calculation of labor } \\
\text { cost (meal, transportation, examinations, health plan, etc.) }\end{array}$ & Budget \\
\hline 68 & $\begin{array}{l}\text { Lack of consideration of price readjustment (labor, material, } \\
\text { subcontractors, etc.) }\end{array}$ & Budget \\
\hline 69 & $\begin{array}{l}\text { Unit cost of budgeted resources lower than that practiced for lack of } \\
\text { quotation or lagged database }\end{array}$ & Budget \\
\hline 70 & The budget sector generally does not perform the work & Budget \\
\hline 71 & Lack of productivity monitoring & Planning / Cost Control \\
\hline 72 & Lack of planning in materials purchases and contracting services & Planning / Cost Control \\
\hline 73 & Initial planning inefficient or impracticable & Planning / Cost Control \\
\hline 74 & Lack of planning monitoring & Planning / Cost Control \\
\hline 75 & Lack of cost monitoring & Planning / Cost Control \\
\hline 76 & Low labor productivity & Production / Quality \\
\hline 77 & Waste materials & Production / Quality \\
\hline 78 & Low equipment efficiency & Production / Quality \\
\hline 79 & Errors during construction caused by subcontractors & Production / Quality \\
\hline 80 & Rework due to errors during construction & Production / Quality \\
\hline 81 & Lack of quality control & Production / Quality \\
\hline 82 & Delay in mobilization and start of service & Production / Quality \\
\hline 83 & Maintenance after delivery of the work & Production / Quality \\
\hline 84 & Excess overtime & Production / Quality \\
\hline 85 & Execution of services out of scope & Production / Quality \\
\hline
\end{tabular}


The interviewees of the three groups performed an assessment of 1 to 5 according to the Likert scale when frequency, severity, and importance. The 10 most frequent causes can be observed in Table 3.

Table 3: Frequency of cost overrun causes

\begin{tabular}{|c|l|l|l|}
\hline No & \multicolumn{1}{|c|}{ Directors } & \multicolumn{1}{|c|}{ Project manager } & \multicolumn{1}{c|}{ Area Managers } \\
\hline 1 & $\begin{array}{l}\text { Lack of design detail during } \\
\text { budgeting }\end{array}$ & Changes/additives in scope & $\begin{array}{l}\text { Lack of design detail during } \\
\text { budgeting }\end{array}$ \\
\hline 3 & $\begin{array}{l}\text { Delay in the preparation of } \\
\text { design projects }\end{array}$ & $\begin{array}{l}\text { Political pressures to meet } \\
\text { deadlines }\end{array}$ & Waste materials \\
\hline 4 & $\begin{array}{l}\text { High indirect cost in periods of } \\
\text { low productivity }\end{array}$ & $\begin{array}{l}\text { Lack of design detail during } \\
\text { budgeting }\end{array}$ & $\begin{array}{l}\text { Unrealistic initial budget } \\
\text { assumptions }\end{array}$ \\
\hline 5 & $\begin{array}{l}\text { Low labor productivity } \\
\text { Changes/additives in scope }\end{array}$ & Excess overtime & $\begin{array}{l}\text { High indirect cost in periods of } \\
\text { low productivity }\end{array}$ \\
\hline 6 & $\begin{array}{l}\text { Excess overtime } \\
\text { The budget sector generally } \\
\text { does not perform the work }\end{array}$ & $\begin{array}{l}\text { Restrictions such as } \\
\text { expropriations and interference }\end{array}$ & $\begin{array}{l}\text { Excessive bureaucracy on the } \\
\text { part of public entities }\end{array}$ \\
\hline 8 & $\begin{array}{l}\text { Lack of productivity } \\
\text { monitoring }\end{array}$ & $\begin{array}{l}\text { Unrealistic initial budget } \\
\text { assumptions }\end{array}$ & Low labor productivity \\
\hline 9 & $\begin{array}{l}\text { Late in reviewing design } \\
\text { documents }\end{array}$ & Waste materials & $\begin{array}{l}\text { Late in reviewing design } \\
\text { documents }\end{array}$ \\
\hline 10 & Waste materials & $\begin{array}{l}\text { High indirect cost in periods of } \\
\text { low productivity }\end{array}$ & Project design incompatibility \\
\hline
\end{tabular}

As can be seen at the tables above, the frequency-related causes, common to all groups are: changes/additives in the scope; lack of design detail during budgeting; waste of materials.

With regard to severity, the 10 causes that generate the greatest impact according to the interviewees can be observed in Table 4 .

Table 4: Severity of cost overrun causes

\begin{tabular}{|c|c|c|c|}
\hline No & Directors & Project manager & Area Managers \\
\hline 1 & $\begin{array}{l}\text { Lack of design detail during } \\
\text { budgeting }\end{array}$ & $\begin{array}{l}\text { Restrictions such as } \\
\text { expropriations and interference }\end{array}$ & $\begin{array}{l}\text { Lack of knowledge of the real } \\
\text { productivity in the elaboration } \\
\text { of the compositions }\end{array}$ \\
\hline 2 & Low labor productivity & $\begin{array}{l}\text { Lack of design detail during } \\
\text { budgeting }\end{array}$ & $\begin{array}{l}\text { High indirect cost in periods of } \\
\text { low productivity }\end{array}$ \\
\hline 3 & $\begin{array}{l}\text { High indirect cost in periods of } \\
\text { low productivity }\end{array}$ & Undefined scope & Undefined scope \\
\hline 4 & $\begin{array}{l}\text { Lack of knowledge of the real } \\
\text { productivity in the elaboration } \\
\text { of the compositions }\end{array}$ & Mistakes in design documents & $\begin{array}{l}\text { Unrealistic initial budget } \\
\text { assumptions }\end{array}$ \\
\hline 5 & $\begin{array}{l}\text { Lack/inefficiency of contract } \\
\text { administration }\end{array}$ & Waste materials & Error in raising quantitative \\
\hline 6 & $\begin{array}{l}\text { Delay in the preparation of } \\
\text { design projects }\end{array}$ & $\begin{array}{l}\text { Unrealistic initial budget } \\
\text { assumptions }\end{array}$ & $\begin{array}{l}\text { Lack of design detail during } \\
\text { budgeting }\end{array}$ \\
\hline
\end{tabular}




\begin{tabular}{|l|l|l|l|}
\hline 7 & Error in raising quantitative & $\begin{array}{l}\text { Lack of knowledge of the real } \\
\text { productivity in the elaboration } \\
\text { of the compositions }\end{array}$ & Low labor productivity \\
\hline 8 & $\begin{array}{l}\text { Lack of productivity } \\
\text { monitoring }\end{array}$ & $\begin{array}{l}\text { Lack of consideration of } \\
\text { unproductiveness in the } \\
\text { calculation of labor }\end{array}$ & Changes/additives in scope \\
\hline
\end{tabular}

\begin{tabular}{|c|l|l|l|}
\hline No & \multicolumn{1}{|c|}{ Directors } & \multicolumn{1}{c|}{ Project manager } & \multicolumn{1}{c|}{ Area Managers } \\
\hline 9 & $\begin{array}{l}\text { Initial planning inefficient or } \\
\text { impracticable }\end{array}$ & $\begin{array}{l}\text { Lack of cost monitoring } \\
\text { resources of budgeted } \\
\text { practiced for lack of quotation } \\
\text { or lagged database }\end{array}$ \\
\hline 10 & Changes/additives in scope & Excess overtime & $\begin{array}{l}\text { Late in reviewing design } \\
\text { documents }\end{array}$ \\
\hline
\end{tabular}

The common causes for the 3 groups are budget-related. They are: lack of knowledge of the real productivity in the elaboration of the compositions and lack of design detail during budgeting.

Finally, the 10 most important causes can be observed in Table 5.

Table 5: Importance of cost overrun causes

\begin{tabular}{|c|c|c|c|}
\hline No & Directors & Project manager & Area Managers \\
\hline 1 & $\begin{array}{l}\text { Lack of design detail during } \\
\text { budgeting }\end{array}$ & Changes/additives in scope & $\begin{array}{l}\text { Lack of design detail during } \\
\text { budgeting }\end{array}$ \\
\hline 2 & Changes/additives in scope & $\begin{array}{l}\text { Lack of design detail during } \\
\text { budgeting }\end{array}$ & $\begin{array}{l}\text { High indirect cost in periods of } \\
\text { low productivity }\end{array}$ \\
\hline 3 & Low labor productivity & $\begin{array}{l}\text { Restrictions such as } \\
\text { expropriations and interference }\end{array}$ & Changes/additives in scope \\
\hline 4 & $\begin{array}{l}\text { High indirect cost in periods of } \\
\text { low productivity }\end{array}$ & Undefined scope & $\begin{array}{l}\text { Unrealistic initial budget } \\
\text { assumptions }\end{array}$ \\
\hline 5 & $\begin{array}{l}\text { Delay in the preparation of } \\
\text { design projects }\end{array}$ & Excess overtime & $\begin{array}{l}\text { Lack of knowledge of the real } \\
\text { productivity in the elaboration } \\
\text { of the compositions }\end{array}$ \\
\hline 6 & $\begin{array}{l}\text { Lack of productivity } \\
\text { monitoring }\end{array}$ & Waste materials & Low labor productivity \\
\hline 7 & $\begin{array}{l}\text { Lack of knowledge of the real } \\
\text { productivity in the elaboration } \\
\text { of the compositions }\end{array}$ & $\begin{array}{l}\text { Unrealistic initial budget } \\
\text { assumptions }\end{array}$ & $\begin{array}{l}\text { Late in reviewing design } \\
\text { documents }\end{array}$ \\
\hline 8 & Excess overtime & $\begin{array}{l}\text { High indirect cost in periods of } \\
\text { low productivity }\end{array}$ & Waste materials \\
\hline 9 & $\begin{array}{l}\text { Lack of planning in materials } \\
\text { purchases and contracting } \\
\text { services }\end{array}$ & $\begin{array}{l}\text { Late in reviewing design } \\
\text { documents }\end{array}$ & Undefined scope \\
\hline 10 & $\begin{array}{l}\text { Initial planning inefficient or } \\
\text { impracticable }\end{array}$ & $\begin{array}{l}\text { Political pressures to meet } \\
\text { deadlines }\end{array}$ & Project design incompatibility \\
\hline
\end{tabular}

Finally, with regard to importance, the common causes for the three groups of interviewees are: lack of design detail during budgeting; changes/additives of scope; high indirect cost in periods of low productivity.

As mentioned, the causes of cost overrun were classified into 11 departments and from the compilation of all data, the tables 6 to 9 below present the frequency, severity and importance 
indices by each department and by groups of respondents. It is possible to identify the main department in which to act to avoid the occurrence of these causes.

Table 6: Ranking of departments of cost overrun by directors

\begin{tabular}{|l|c|c|c|c|c|c|}
\hline \multirow{2}{*}{\multicolumn{1}{c|}{ Departments of cost overrun }} & \multicolumn{2}{c|}{ Frequency } & \multicolumn{2}{c|}{ Severity } & \multicolumn{2}{c|}{ Importance } \\
\cline { 2 - 7 } & Index & Rank & Index & Rank & Index & Rank \\
\hline Planning / Cost Control & 66,18 & 1 & 72,73 & 1 & 48,13 & 1 \\
\hline Budget & 56,51 & 5 & 72,48 & 2 & 40,96 & 2 \\
\hline Production / Quality & 63,27 & 2 & 64,18 & 6 & 40,61 & 3 \\
\hline External & 56,36 & 6 & 68,36 & 3 & 38,53 & 4 \\
\hline Client & 57,64 & 3 & 66,55 & 4 & 38,35 & 5 \\
\hline Engineering / Consulting & 56,59 & 4 & 61,82 & 7 & 34,98 & 6 \\
\hline Contract Management & 53,94 & 7 & 64,85 & 5 & 34,98 & 7 \\
\hline Directorship & 49,87 & 8 & 58,16 & 8 & 29,00 & 8 \\
\hline Commercial / Contractual Administration & 46,36 & 10 & 56,14 & 9 & 26,03 & 9 \\
\hline Political Factors & 49,39 & 9 & 51,36 & 11 & 25,37 & 10 \\
\hline Environmental Factors & 37,27 & 11 & 55,00 & 10 & 20,50 & 11 \\
\hline
\end{tabular}

Table 7: Ranking of departments of cost overrun by project managers

\begin{tabular}{|l|c|c|c|c|c|c|}
\hline \multirow{2}{*}{\multicolumn{1}{c|}{ Departments of cost overrun }} & \multicolumn{2}{|c|}{ Frequency } & \multicolumn{2}{c|}{ Severity } & \multicolumn{2}{c|}{ Importance } \\
\cline { 2 - 7 } & Index & Rank & Index & Rank & Index & Rank \\
\hline Client & 68,00 & 1 & 73,41 & 3 & 49,92 & 1 \\
\hline Production / Quality & 64,50 & 2 & 71,95 & 4 & 46,41 & 2 \\
\hline Planning / Cost Control & 62,35 & 3 & 74,35 & 2 & 46,36 & 3 \\
\hline Budget & 59,76 & 4 & 74,71 & 1 & 44,65 & 4 \\
\hline Engineering / Consulting & 58,22 & 5 & 68,97 & 6 & 40,16 & 5 \\
\hline Contract Management & 56,83 & 6 & 67,13 & 8 & 38,15 & 6 \\
\hline External & 54,82 & 7 & 66,82 & 9 & 36,64 & 7 \\
\hline Directorship & 53,28 & 8 & 68,24 & 7 & 36,35 & 8 \\
\hline Political Factors & 52,25 & 9 & 60,99 & 11 & 31,87 & 9 \\
\hline Commercial / Contractual Administration & 50,88 & 10 & 62,50 & 10 & 31,80 & 10 \\
\hline Environmental Factors & 40,59 & 11 & 69,85 & 5 & 28,35 & 11 \\
\hline
\end{tabular}

Table 8: Ranking of departments of cost overrun by project managers

\begin{tabular}{|l|c|c|c|c|c|c|}
\hline \multirow{2}{*}{\multicolumn{1}{c|}{ Departments of cost overrun }} & \multicolumn{2}{c|}{ Frequency } & \multicolumn{2}{c|}{ Severity } & \multicolumn{2}{c|}{ Importance } \\
\cline { 2 - 7 } & Index & Rank & Index & Rank & Index & Rank \\
\hline Production / Quality & 65,89 & 1 & 72,32 & 4 & 47,65 & 1 \\
\hline Client & 61,90 & 3 & 73,65 & 2 & 45,59 & 2 \\
\hline Engineering / Consulting & 64,47 & 2 & 69,87 & 6 & 45,05 & 3 \\
\hline Budget & 58,11 & 6 & 77,47 & 1 & 45,02 & 4 \\
\hline Planning / Cost Control & 61,68 & 4 & 72,63 & 3 & 44,80 & 5 \\
\hline External & 56,42 & 7 & 71,37 & 5 & 40,27 & 6 \\
\hline Contract Management & 58,60 & 5 & 67,54 & 7 & 39,58 & 7 \\
\hline Directorship & 55,73 & 8 & 63,91 & 10 & 35,61 & 8 \\
\hline Commercial / Contractual Administration & 53,55 & 9 & 65,66 & 8 & 35,16 & 9 \\
\hline Political Factors & 51,93 & 10 & 56,73 & 11 & 29,46 & 10 \\
\hline Environmental Factors & 40,79 & 11 & 64,21 & 9 & 26,19 & 11 \\
\hline
\end{tabular}


Table 9: Ranking of departments of cost overrun by all parties

\begin{tabular}{|l|c|c|c|c|c|c|}
\hline \multirow{2}{*}{\multicolumn{1}{c|}{ Departments of cost overrun }} & \multicolumn{2}{c|}{ Frequency } & \multicolumn{2}{c|}{ Severity } & \multicolumn{2}{c|}{ Importance } \\
\cline { 2 - 7 } & Index & Rank & Index & Rank & Index & Rank \\
\hline Planning / Cost Control & 62,98 & 3 & 73,28 & 2 & 46,15 & 1 \\
\hline Production / Quality & 64,78 & 1 & 70,28 & 4 & 45,52 & 2 \\
\hline Client & 63,11 & 2 & 71,90 & 3 & 45,38 & 3 \\
\hline Budget & 58,34 & 5 & 75,31 & 1 & 43,93 & 4 \\
\hline Engineering / Consulting & 60,37 & 4 & 67,66 & 6 & 40,85 & 5 \\
\hline External & 55,83 & 7 & 69,02 & 5 & 38,53 & 6 \\
\hline Contract Management & 56,67 & 6 & 66,76 & 7 & 37,83 & 7 \\
\hline Directorship & 53,46 & 8 & 64,15 & 8 & 34,29 & 8 \\
\hline Commercial / Contractual Administration & 50,90 & 10 & 62,29 & 10 & 31,71 & 9 \\
\hline Political Factors & 51,45 & 9 & 57,00 & 11 & 29,33 & 10 \\
\hline Environmental Factors & 39,89 & 11 & 64,06 & 9 & 25,56 & 11 \\
\hline
\end{tabular}

The data show that the directors consider planning and cost control the most important department in cost overrun. The evaluation of project managers shows that the behavior of the client is the most relevant causes. In the view of area managers, the production and quality departments are related the most important causes.

With all the data collected, the Spearman correlation coefficient was calculated with the objective of assessing if the points of view of the 3 groups agree. As can be seen in Tables 10 to 13, the coefficients indicate that the responses of the groups present a high degree of agreement.

Table 10: Spearman correlation with analysis of the results of directors and project managers

\begin{tabular}{|l|c|c|c|c|c|}
\hline \multicolumn{1}{|c|}{ Department } & Director & $\begin{array}{c}\text { Project } \\
\text { manager }\end{array}$ & $\mathbf{d}=\mathbf{x}-\mathbf{y}$ & $\mathbf{d}^{2}$ & $\mathbf{r}_{\mathbf{s}}$ \\
\hline \multicolumn{1}{|c|}{$\mathrm{n}=11$} & $\mathrm{x}$ & $\mathrm{y}$ & 0 & 38 & $\mathbf{0 , 8 3}$ \\
\hline Client & 5 & 1 & 4 & 16 & 1 \\
\hline Commercial / Contractual Administration & 9 & 10 & -1 & 0 \\
\hline Directorship & 8 & 8 & 0 & 1 \\
\hline Engineering / Consulting & 6 & 5 & 1 & 0 \\
\hline Environmental Factors & 11 & 11 & 0 & 1 \\
\hline Political Factors & 10 & 9 & 1 & 9 \\
\hline External & 4 & 7 & -3 & 1 \\
\hline Contract Management & 7 & 6 & 1 & 4 \\
\hline Budget & 2 & 4 & -2 & 4 \\
\hline Planning / Cost Control & 1 & 3 & -2 & 1 \\
\hline Production / Quality & 3 & 2 & 1 & 1 \\
\hline
\end{tabular}

Table 11: Spearman correlation with analysis of the results of directors and area managers

\begin{tabular}{|l|c|c|c|c|c|}
\hline \multicolumn{1}{|c|}{ Department } & Director & $\begin{array}{c}\text { Area } \\
\text { Manager }\end{array}$ & $\mathbf{d}=\mathbf{x}-\mathbf{y}$ & $\mathbf{d}^{2}$ & $\mathbf{r s}_{\text {s }}$ \\
\hline \multicolumn{1}{|c|}{$\mathrm{n}=11$} & $\mathrm{x}$ & $\mathrm{y}$ & 0 & 46 & $\mathbf{0 , 7 9}$ \\
\hline Client & 5 & 2 & 3 & 9 & 0 \\
\hline Commercial / Contractual Administration & 9 & 9 & 0 & 0 \\
\hline Directorship & 8 & 8 & 0 & 0 \\
\hline Engineering / Consulting & 6 & 3 & 3 & 9 \\
\hline
\end{tabular}




\begin{tabular}{|l|c|c|c|c|}
\hline Environmental Factors & 11 & 11 & 0 & 0 \\
\hline Political Factors & 10 & 10 & 0 & 0 \\
\hline External & 4 & 6 & -2 & 4 \\
\hline Contract Management & 7 & 7 & 0 & 0 \\
\hline Budget & 2 & 4 & -2 & 4 \\
\hline Planning / Cost Control & 1 & 5 & -4 & 16 \\
\hline Production / Quality & 3 & 1 & 2 & 4 \\
& & & & \\
\hline
\end{tabular}

Table 12: Spearman correlation with analysis of the results of project managers and area managers

\begin{tabular}{|l|c|c|c|c|c|}
\hline \multicolumn{1}{|c|}{$\mathbf{n}$} & $\begin{array}{c}\text { Area } \\
\text { Manager }\end{array}$ & $\begin{array}{c}\text { Project } \\
\text { manager }\end{array}$ & $\mathbf{d}=\mathbf{x}-\mathbf{y}$ & $\mathbf{d}^{2}$ & $\mathbf{r}_{\mathbf{s}}$ \\
\hline \multicolumn{1}{|c|}{$\mathrm{n}=11$} & $\mathrm{x}$ & $\mathrm{y}$ & 0 & 14 & $\mathbf{0 , 9 4}$ \\
\hline Client & 2 & 1 & 1 & 1 & \\
\hline Commercial / Contractual Administration & 9 & 10 & -1 & 1 \\
\hline Directorship & 8 & 8 & 0 & 0 \\
\hline Engineering / Consulting & 3 & 5 & -2 & 4 \\
\hline Environmental Factors & 11 & 11 & 0 & 0 \\
\hline Political Factors & 10 & 9 & 1 & 1 \\
\hline External & 6 & 7 & -1 & 1 \\
\hline Contract Management & 7 & 6 & 1 & 1 \\
\hline Budget & 4 & 4 & 0 & 0 \\
\hline Planning / Cost Control & 5 & 3 & 2 & 4 \\
\hline Production / Quality & 1 & 2 & -1 & 1 \\
\hline
\end{tabular}

Table 13: Spearman rank correlation coefficient

\begin{tabular}{|l|c|}
\hline \multicolumn{1}{|c|}{ Groups } & Index \\
\hline Director e Project manager & 0,83 \\
\hline Director e Area Manager & 0,79 \\
\hline Area Manager e Project manager & 0,94 \\
\hline
\end{tabular}

\subsection{Conclusions}

The present study show the point of view of 47 professionals in the construction area, with many years of experience (between 10 and 28 years) and experience in works of various sizes throughout 16 states of Brazil. These professionals belong to 3 major hierarchical groups within a company with 11 directors, 17 project managers and 19 area managers.

On average, respondents pointed out that $71 \%$ of contracts have their costs increased by the end of the project by $14 \%$. The results present a very large correlation in the perception of the causes of the cost overrun in the works as presented in table 22. Project managers and area managers presented a coefficient of $94 \%$ Spearman correlation. The directors and project managers with $83 \%$ and the directors and area managers with $79 \%$.

The result of project managers group shows that customer is the major causer in cost overrun of the work and secondly the production department. On the other hand, the group of area managers 
understands that the production department are the main responsible for the increase of costs and secondly the client. The result of the directors is more related to internal factors of planning, control, and monitoring and therefore they understand that the department of planning and cost control is the main cause of the cost overrun in the works and secondly the department of budget, being in fifth place the client.

\subsection{Recommendations for Future Studies}

A recommendation for future study would be to deepen the profile of the client to better understand the impacts on the results of construction contracts related to customer types (public, private and mixed) and types of contract (unit price, global or mixed price). The study reported a very large customer impact on costs overrun and loss of profitability.

When talking with professionals in the field, many reported difficulties in the relationship with the client, especially in the public department, which presents delays in payment, constant changes in scope and sequencing to meet third party interests. Another problem reported to the public client is the constant changes in tax inspectors according to political interests, which often ends up blocking the process and losing the contract's history. For these reasons, a customer-facing study would be interesting.

\section{Acknowledgement}

The authors would like to thank the collaboration of all the interviewees in providing the data needed to prepare and complete this study. Also, we are thankful to the support of the National Council for Scientific and Technological Development CNPq for its financial support.

\section{References}

[1] H. de P. Santos, C. M. D. Starling, P. R. P. Andery, Um estudo sobre as causas de aumentos de custos e de prazos em obras de edificações públicas municipais. Ambiente Construído. 15, 225-242 (2015).

[2] G. A. Niazi, N. Painting, Significant factors causing cost overruns in the construction industry in Afghanistan. Science Direct . 182, 510-517 (2016).

[3] N. Azhar, R. U. Farooqui, S. M. Ahmed, Cost Overrun Factors In Construction Industry of Pakistan. First International Conference on Construction In Developing Countries (ICCIDC-I) "Advancing and Integrating Construction Education, Research \& Practice" August 4-5, 2008, Karachi, Pakistan, 499508 (2008).

[4] A. A. A. Azis, A. H. Memon, I. A. Rahman, A. T. A. Karim, Controlling cost overrun factors in construction projects in malaysia. Research Journal of Applied Sciences, Engineering and Technology. 5, 2621-2629 (2013).

[5] A. Enshassi, J. Al - Najjar, M. Kumaraswamy, Delays and cost overruns in the construction projects in the Gaza Strip. Journal of Financial Management of Property and Construction. 14, 126 - 151 (2009).

[6] N. I. El-Sawalhi, An Overhead Costs Assessment for Construction Projects at Gaza Strip. American Journal of Civil Engineering. 3, 95 (2015).

[7] S. A. Assaf, S. Al-Hejji, Causes of delay in large construction projects. International Journal of Project Management. 24, 349-357 (2006).

[8] Senouci, A., Ismail, A. \& Eldin, N. Time Delay and Cost Overrun in Qatari Public Construction Projects. in Procedia Engineering 164, 368-375 (Elsevier Ltd, 2016).

[9] P. F. Kaming, P. O. Olomolaiye, G. D. Holt, F. C. Harris, Factors influencing construction time and cost overruns on high-rise projects in Indonesia. Construction Management and Economics. 15, 83-94 (1997).

[10] D. Arditi, G. T. Akan, S. Gurdamar, Cost overruns in public projects. International Journal of Project Management. 3, 218-224 (1985).

[11] Y. M. Cheng, An exploration into cost-influencing factors on construction projects. International Journal of Project Management. 32, 850-860 (2014).

[12] Polat, G., Okay, F. \& Eray, E. Factors affecting cost overruns in micro-scaled construction companies. 
International Journal of Sustainable Construction Engineering \& Technology (ISSN: 2180-3242) Vol 9, No 1, 2018

in Procedia Engineering 85, 428-435 (Elsevier Ltd, 2014). 